\title{
IMPACT OF DIFFERENT LITTER COMBINATIONS ON JAPANESE QUAIL GROWTH PERFORMANCE AND INDOOR AIR CONDITION
}

\author{
M.F.A. Farghly, M. El-Sagheer ${ }^{1}$ and H.Y. El-Hammady \\ Department of Poultry Production, Faculty of Agriculture, Assiut University, 71526, Assiut, Egypt \\ ${ }^{1}$ Corresponding author:(sagheer68@yahoo.com)
}

\section{SUMMARY}

One hundred and eighty, one day old Japanese Quail chicks were randomly assigned into three equal groups, each of 60 chicks to investigate their growth performance, leg problems, breast blisters and airborne dust particulates as well as the litter conditions affected by raising birds on some litters composed of different materials during the period from 0 to 8 weeks of age. Chicks in the first group (control; C) were raised on shopped wheat straw litter, while those in the second and third groups (L1 and L2) were raised on mixed litters composed of $25 \%$ of each of rice hulls, wheat straw, wood sawdust and clay as well as on $20 \%$ of each of rice hulls, wheat straw, wood sawdust and $40 \%$ clay, respectively. All birds were raised under similar environmental, managerial and hygienic conditions.

The achieved results revealed that birds of the control (C), L1 and L2 groups had almost similar body weight, feed consumption and feed conversion values, while birds of L1 group had significantly $(P \leq 0.05)$ higher body weight gain and less leg problems, breast blisters, mortality percentages as compared to those of $C$ and L2 groups. There were only very limited differences in the litter moisture percentage, bacterial count, airborne organic dust particulates and ammonia concentrations among the tested litter types.

The economic efficiency (EE), in relation to the use of the litter type exceeded remarkably in the L1 than those of C and L2 groups. Therefore, the use of the clay at a level of $25 \%$ as a component of the litter for growing Japanese quail is highly recommended to achieve good growth performance coincided with adequate litter conditions and airborne dust particulates.

\section{Keywords: Performance, clay, airborne and litter conditions, Japanese quail}

\section{INTRODUCTION}

The sustainable and controlled adequate environment in poultry house is very important, so that birds can achieve the best possible production performance. The cost and specifications of the litter are among the limiting factors that pronouncedly affect the vitality and production potentially of birds. Therefore, the litter components have to be dry and specified not only with high water-holding capacity but also with pronounced ability to release quickly the absorbed moisture. Shopped wheat straw and wood shavings are the most effective local cheap and available litter materials for raising poultry.

It is well known that, broilers are prone to litter-eating, therefore it is important to evaluate the efficiency of litter materials for the safety and growth performance of broilers (Adebayo et al., 2009).The high absorbent nature, good drying time, low prices, non-toxicity and availability are among the factors that determine the adequacy of materials to be used as good litter sources. It is worth to mention that the available information in the literature on the effects of using clay as litter components for the broiler performance is very limited. Therefore, it was seen possible to utilize indirectly the effects of using clay in poultry rations on their production performance. Andersson et al. (1990) reported that using natural clays in chicken broilers and laying rations stimulated their appetite. Andronikashvili et al. (1994) reported that the addition of natural clays in poultry rations improved their digestibility coefficient and nutritive values. Taylor (1999) reported that using acidulated clay as a litter component reduced ammonia levels in the indoor environment of broilers house as compared to those of the untreated group. McWard and Taylor (2000) stated that the use of clay in the litter of broilers could control air ammonia percentage and improve the growth performance of the young birds.

Recently, there is a new interest in using natural zeolites as a mean for reducing odors and ammonia emissions from broiler houses (McCrory and Hobbs, 2001), as feed additive (Christaki et al., 2001) and supplement in bedding materials (Eleroglu and Yalcin, 2005). Therefore, the present study aimed to assess the effect of using clay at levels of 25 or $40 \%$ as a litter component on the indoor air condition, vitality and growth performance of Japanese quail.

\section{MATERIALS AND METHODS}

The present work was performed at the Poultry Research Farm, Faculty of Agriculture, Assiut University Upper Egypt. 


\section{Experimental Birds:}

One hundred and eighty, one day old Japanese quail chicks were sexed, wing banded, individually weighed and randomly distributed into three groups, each of 60 chicks, each including three replicates having equal numbers of males and females. Birds in the first group (control, C) were raised on wheat straw litter, while those in the second and third groups (T1 and T2) were raised on mixed litter composed of $25 \%$ of each of rice hulls, wheat straw, wood sawdust and clay as well as of $20 \%$ of each of rice hulls, wheat straw, wood sawdust and $40 \%$ clay, respectively. All birds were raised under similar environmental, managerial and hygienic conditions on a litter of three $\mathrm{cm}$ thickness. The newly hatched chicks were exposed during the first three days of age to continuous lighting for 24 hrs/daily. Thereafter, the photoperiod was decreased gradually two hr/wk) to be adjusted at12hrs light and 10 Luxes light intensity, at 6 weeks of age and then lasted constant till 8 weeks of age. Feed and water were available all the time. The composition and calculated analysis of the experimental diets are shown in Table (1).

Table 1. Composition and calculated analysis of the experimental diets

\begin{tabular}{lclc}
\hline Ingredients & Starter $(\%)$ & \multicolumn{2}{c}{ Calculated analysis*** } \\
\hline Yellow corn & 53.0 & Protein $(\%)$ & 26.0 \\
Soybean meal $(44 \%)$ & 34.6 & ME $(\mathrm{KCal} / \mathrm{Kg}$ diet $)$ & 2850 \\
Concentrate $(52 \% \mathrm{CP})^{*}$ & $12.0 *$ & Calcium $(\%)$ & 0.90 \\
Salt $(\mathrm{NaCl})$ & 0.25 & Available phosphorus $(\%)$ & 0.45 \\
Di-calcium phosphate & 0.15 & & \\
Limestone & --- & & \\
Total & $\mathbf{1 0 0}$ & & \\
\hline
\end{tabular}

"The broiler concentrate contains: Crude protein, 52\%; Crude fiber, $2 \%$; Crude fat, 2.4\%;Ca, 7.6\%;P (Available), 2.6\%; Methionine, 1.7\%; Lysine, 2.5\%; Salt, 2\%; ME,2650 Kcal/Kg. Each kilogram of broiler concentrate contains the following levels of vitamins and minerals: Vit A, $120000 \mathrm{IU}$; vit D3, $22000 \mathrm{IU}$; vit E, $10000 \mathrm{mg}$; vit K, 2000 mg; B1, 1000 mg; B2, 5000 mg; B6, 15000 mg; B12, 10 mg; Biotin, 50 mg; Dicalcium phosphate, 1000 mg; Pantothenic acid, 120 mg; Folic acid ,20 mg; Niacin, 450 mg; Chorine chloride, 3600 mg; Fe, 300 mg; I, 10 mg; Mn, 1000 mg; Cu, 1000 mg; Se, 2 mg; Co, 1 mg; Zn, 600 mg.

** Calculated according to NRC (1994).

\section{The Chemical Composition and Analysis of Clay}

The used clay was identified and analyzed in the scientific Labs of Geology and Physics Departments, Faculty of Science, Assiut University. It included the following oxides: $\mathrm{SiO}_{2}$ (52.6), $\mathrm{Al}_{2} \mathrm{O}_{3}$ (19.75\%), $\mathrm{Fe}_{2} \mathrm{O} 3$ (5.88\%), $\mathrm{CaO}(7.55 \%), \mathrm{MgO}$ (3.03\%), K2O (0.98\%), Cl $(1.99 \%)$ and others $(8.22 \%)$.

\section{Parameters and Criteria Studied}

The averages of body weights $(\mathrm{BW})$ at 0,2 , 4,6 , and 8 weeks of age and the body weight gain (BWG) were calculated biweekly. The weekly averages of feed consumption (FC) and feed conversion values ( $\mathrm{g}$ feed/g gain; FCR) were calculated biweekly, from 0 to 8 weeks of age. The daily dead birds were recorded daily and expressed as mortality percentage during the experimental period. At 8 weeks of age, birds per replicate were examined and scored (on a scale of 1 to 5) for leg problems and breast blisters.

Eighty one litter samples were taken from each group to determine the bacterial count (Klement et al., 1990) and the moisture content in the litters as the birds aged 4, 6, and 8 weeks. Also, a total number of eighty one samples (as the birds aged 4, 6, and 8 weeks), at 10 AM were taken from each group to determine the concentration of airborne ammonia inside the poultry house (Nodvor, 1976) and the suspended airborne organic dust particulates, expressed as $\mathrm{mg} / \mathrm{m} 3$ in the experimental rooms by using a specialized apparatus (Model No PS-33).

The economical efficiency based on the average costs of feed consumed and litter quantities used as well as the average income/bird were calculated. The net revenue per bird was estimated as the difference between the total sale price (LE), and the costs (LE) of feeds consumed and litter used, according to the prevailing prices in the local Egyptian market during the experimental period during the experiment.

\section{Statistical Analysis}

Data collected were subjected to analysis of variance by applying the General Linear Models Procedure of SAS software (SAS Institute, version $6.12,1996)$. Duncan (1955) was used to detect differences among means of different groups.

\section{RESULTS AND DISCUSSION}

\section{Body Weight (BW) and Body Weight Gain (BWG)}

Data of the BW and BWG presented in Table 2 , showed no significant $(\mathrm{P} \leq 0.05)$ differences in BW among groups, however the birds in L1 recorded the highest BW surpassing those of groups ( $\mathrm{C}$ and $\mathrm{L} 2)$. The birds of $\mathrm{L} 1$ gained significantly more $(\mathrm{P} \leq 0.05)$ weight than those of $\mathrm{C}$ and L2 groups during 4-6, 6-8 as well as in the whole experimental period. 
Table 2. Means \pm SE of body weight (BW), body weight gain (BWG), feed consumption (FC) and feed conversion ratio (FCR) of growing Japanese quail as affected by litter type

\begin{tabular}{|c|c|c|c|c|}
\hline \multirow{2}{*}{ Traits } & \multirow{2}{*}{$\begin{array}{l}\text { Age } \\
\text { (weeks) }\end{array}$} & \multicolumn{3}{|c|}{ Groups } \\
\hline & & $\mathbf{C}$ & L1 & L2 \\
\hline \multirow{5}{*}{ BW (g) } & 0 & $7.8 \pm 1.0$ & $7.4 \pm 1.1$ & $7.6 \pm 0.9$ \\
\hline & 2 & $52.6 \pm 1.7$ & $55.3 \pm 2.8$ & $52.4 \pm 2.6$ \\
\hline & 4 & $124.6 \pm 4.2$ & $129.6 \pm 4.6$ & $124.1 \pm 3.3$ \\
\hline & 6 & $177.4 \pm 5.3$ & $184.4 \pm 3.6$ & $177.2 \pm 5.2$ \\
\hline & 8 & $205.1 \pm 5.3$ & $214.2 \pm 4.1$ & $204.9 \pm 5.3$ \\
\hline \multirow{5}{*}{$\begin{array}{c}\text { BWG } \\
\text { (g/bird/day) }\end{array}$} & 0 - 2 & $3.20 \pm 0.66$ & $3.42 \pm 0.55$ & $3.20 \pm 0.66$ \\
\hline & $2-4$ & $5.14 \pm 1.10$ & $5.31 \pm 0.75$ & $5.14 \pm 1.10$ \\
\hline & $4-6$ & $3.78^{\mathrm{b}} \pm 1.16$ & $3.91^{\mathrm{a}} \pm 1.02$ & $3.78^{\mathrm{b}} \pm 1.16$ \\
\hline & $6-8$ & $1.98^{\mathrm{b}} \pm 0.22$ & $2.13^{\mathrm{a}} \pm 0.25$ & $1.98^{\mathrm{b}} \pm 0.22$ \\
\hline & Overall mean & $3.52^{\mathrm{b}} \pm \mathbf{0 . 7 8}$ & $3.69^{\mathrm{a}} \pm 0.92$ & $3.49^{\mathrm{b}} \pm 1.0$ \\
\hline \multirow{5}{*}{$\begin{array}{c}\text { FC } \\
\text { (g/bird/day) }\end{array}$} & $0-2$ & $8.1 \pm 0.7$ & $7.7 \pm 0.7$ & $8.0 \pm 0.6$ \\
\hline & $2-4$ & $12.2 \pm 1.1$ & $12.1 \pm 0.6$ & $12.1 \pm 1.0$ \\
\hline & $4-6$ & $13.8 \pm 0.9$ & $14.0 \pm 0.7$ & $13.9 \pm 0.8$ \\
\hline & $6-8$ & $16.4 \pm 0.8$ & $16.8 \pm 1.1$ & $16.5 \pm 0.9$ \\
\hline & Overall mean & $12.6 \pm 0.9$ & $12.7 \pm 0.5$ & $12.6 \pm 0.8$ \\
\hline \multirow{5}{*}{$\begin{array}{c}\text { FCR } \\
\text { (g feed/g gain) }\end{array}$} & 0 - 2 & $2.53 \pm 0.33$ & $2.23 \pm 0.12$ & $2.53 \pm 0.33$ \\
\hline & $2-4$ & $2.37 \pm 0.41$ & $2.32 \pm 0.18$ & $2.35 \pm 0.41$ \\
\hline & $4-6$ & $3.66 \pm 0.37$ & $3.58 \pm 0.22$ & $3.67 \pm 0.37$ \\
\hline & $6-8$ & $8.28 \pm 0.54$ & $7.88 \pm 0.38$ & $8.33 \pm 0.54$ \\
\hline & Overall mean & $3.59 \pm 0.42$ & $3.43 \pm 0.20$ & $3.58 \pm 0.35$ \\
\hline Leg problems score & 8 & 2.5 & 2.1 & 2.9 \\
\hline Breast blisters score & 8 & 1.7 & 1.7 & 2.0 \\
\hline Mortality rate (\%) & 8 & 8.3 & 6.7 & 11.7 \\
\hline
\end{tabular}

Andersson et al. (1990) stated that incorporation of natural clays in animal rations stimulated the appetite of broilers and laying hens. Andronikashvili et al. (1994) reported that the addition of natural clays in poultry rations improved their digestibility coefficient and nutritive values. McCollum and Galyean (1983) reported that adding the natural clays to beef ration may stimulate the lining layer of the stomach and the intestinal tract, which could increase the production of antibodies and consequently inhibit the onset of nitrites. They also added that, clays could remarkably decrease the frictional rate of liquids passage and permit only the slight food particles in the digestive tract. However, Erwin et al. (1957) reported that using $3 \%$ sodium bentonite clay in cattle rations had no significant effect on the rate of their body weight gain. Also, Swain and Sundaram (2000) found no significant differences in BWG of broilers raised on litters composed of coir dust, saw dust and rice husk.

\section{Feed Consumption (FC) and Feed Conversion (FCR)}

The results showed no significant differences in FC and FCR among the experimental groups; however birds in L1 group had better cumulative
FCR by about 4.5 and $4.2 \%$, respectively than those of birds of C and L2 groups, respectively (Table 2).

These results are in harmony with those obtained by Quisenberry (1968), who stated that the addition of western bentonite clays at 3 or $5 \%$ levels to the rations of chickens pullets improved significantly $(\mathrm{P} \leq 0.05)$ the feed efficiency than that of the controls. Xia et al. (2004) found that rations supplemented with 10$30 \mathrm{gkg}$ of clay improved significantly $(\mathrm{P} \leq 0.05)$ the feed efficiency in chickens broiler. Also, Zlobina (1990) showed that the addition of natural clays $(3 \%)$ to the broilers rations improved significantly $(\mathrm{P} \leq 0.05)$ their feed efficiency. Karamanlis et al. (2008) reported that the broilers fed diets contained 2\% Zeolite consumed higher amounts of feed than those fed the basal diet. The nutrient digestibility and enzymatic activity of gastrointestinal secretion was improved due to addition the clay to the feedstuffs (Alzueta et al., 2002). Similarly, Quisenberry and Bradley (1964) stated that, the addition of bentonite clay at the levels 1 to $5 \%$ to poultry diets improved the caloric efficiency and slowed down the feed passage.

In contrast, Swain and Sundaram (2000) found no significant differences in feed 
conversion of birds raised on litters composed of varied components. Erwin et al. (1957), using3\% sodium bentonite clay in cattle rations reported no significant effect on their feed efficiency. Similarly, Karamanlis et al. (2008) reported that FCR of broilers was not affected by using the natural zeolite.

\section{Leg Problems, Breast Blisters and Mortality:}

The results presented in Table (2), showed that, the litter type had no significant $(\mathrm{P} \leq 0.05)$ effect on leg problems, breast blisters, while the mortality percentage in L1 group $(6.7 \%)$ was less than those (8.3 and $11.7 \%$ ) of C and L2 groups, respectively.

These results are in sympathy with those of Grimes et al. (2006), who found no differences in breast blister, hock condition and foot pad condition index due to the litter materials. They are also in partial agreement with those obtained by Quisenberry (1968), who stated that adding of bentonite clays at a level of 3 or $5 \%$ to the chicken pullets' rations reduced significantly $(\mathrm{P} \leq 0.05)$ the mortality rate than that of their control. The results of Gupta and Gardner (2005) showed a significant $(\mathrm{P} \leq 0.05)$ reduction by $24 \%$ in the toxicity of the clay poultry litter aqueous leachate after 7 days than its corresponding value after one day, which indicated that a remarkable part of the toxic components as well as toxins or odiferous chemicals was adsorbed by the clay litter and the gastrointestinal tract of the animal, respectively. The results of Ouachem and Kaboul (2012) revealed that the clay contributed to enhance significantly $(\mathrm{P}=0.01)$ the immunity of the chicken broilers through increasing the relative weight of bursa Fabricius by about $24.3 \%$.

However, Veltmann et al. (1984) found no pronounced differences in the mortality rate of turkey birds raised on rice hull products versus those kept on wood shavings. Similar results were achieved by Grimes et al. (2006) and Atencio et al. (2010), who found no significant differences in the mortality rates of turkeys and broilers raised on different litter materials. Also, Karamanlis et al. (2008) stated that the mortality rate in the chicken broilers was not affected by supplementing the diets with natural zeolite.

\section{Litter and Air Condition}

The results presented in Table (3), showed insignificant differences in the moisture percentage, ammonia and airborne dust particulates concentrations in the tested litter types. Also, the differences in the bacterial count during the $4^{\text {th }}$ and $6^{\text {th }}$ week were insignificant, however it surpassed significantly $(\mathrm{P} \leq 0.05)$ those of L1 and L2, during $8^{\text {th }}$ week, by 8.1 and $13.4 \%$, respectively.

Table 3. Means $\pm \mathrm{SE}$ of moisture litter, ammonia levels and airborne dust concentrations as affected by litter type

\begin{tabular}{|c|c|c|c|c|}
\hline \multirow{2}{*}{ Items } & \multirow{2}{*}{$\begin{array}{c}\text { Period/Age } \\
\text { (Weeks) }\end{array}$} & \multicolumn{3}{|c|}{ Groups } \\
\hline & & $\mathrm{C}$ & L1 & L2 \\
\hline \multirow{3}{*}{ Moisture (\%) } & 4 & $6.6 \pm 0.7$ & $7.1 \pm 0.8$ & $7.3 \pm 0.5$ \\
\hline & 6 & $9.1 \pm 0.5$ & $9.0 \pm 0.4$ & $8.9 \pm 0.3$ \\
\hline & 8 & $12.7 \pm 0.8$ & $11.9 \pm 0.6$ & $11.5 \pm 0.7$ \\
\hline \multirow{3}{*}{ Bacterial count/one gram $\left(10^{-3}\right)$} & 4 & $6.2 \pm 0.9$ & $6.0 \pm 1.1$ & $5.4 \pm 1.2$ \\
\hline & 6 & $8.1 \pm 0.8$ & $8.1 \pm 1.0$ & $7.9 \pm 1.1$ \\
\hline & 8 & $17.2^{\mathrm{a}} \pm 1.2$ & $15.8^{\mathrm{b}} \pm 1.1$ & $14.9^{\mathrm{b}} \pm 1.1$ \\
\hline \multirow{3}{*}{ Ammonia (PPM) } & 4 & $3.4 \pm 0.4$ & $3.3 \pm 0.3$ & $3.4 \pm 0.4$ \\
\hline & 6 & $6.4 \pm 0.2$ & $6.4 \pm 0.4$ & $6.5 \pm 0.3$ \\
\hline & 8 & $9.0 \pm 0.4$ & $9.3 \pm 0.3$ & $9.0 \pm 0.3$ \\
\hline \multirow{3}{*}{ Airborne Dust (mg/m³) } & 4 & $5.2 \pm 0.3$ & $5.1 \pm 0.3$ & $5.0 \pm 0.4$ \\
\hline & 6 & $6.0 \pm 0.4$ & $6.1 \pm 0.2$ & $6.0 \pm 0.3$ \\
\hline & 8 & $7.0 \pm 0.3$ & $7.0 \pm 0.5$ & $6.9 \pm 0.4$ \\
\hline
\end{tabular}

${ }^{\mathrm{a}}$ and $\mathrm{b}$ Means within each row with different superscripts, are insignificantly different $(\mathrm{P} \leq 0.05)$.

$\mathrm{C}=100 \%$ wheat straw

$\mathrm{L} 1=25 \%$ rice hulls, $25 \%$ wheat straw , $25 \%$ wood sawdust and $25 \%$ clay mix.

L $2=20 \%$ rice hulls, $20 \%$ wheat straw, $20 \%$ wood sawdust and $40 \%$ clay mix.

This is in harmony with the results of ElSagheer et al. (2009) who found insignificant differences in the ammonia and airborne dust particulates concentrations, during growing periods of Dandarawi chicken, by using three tested litter types, except in the $16^{\text {th }}$ and $20^{\text {th }}$ weeks, as well as the bacterial count and moisture percentage (except during $12^{\text {th }}$ week). Also, Lien et al. (1992) stated that the bacteria populations were not affected by the litter type.
Similarly, Kiaei et al. (2002) stated that adding natural zeolite to broiler rations had no effect on the litter moisture percent. Grimes et al. (2006) found no differences in the ammonia level by using some litter types. In contrast, Atapattu et al. (2008) found significant differences in the ammonia concentrations by using different litter types.

However, Quisenberry (1968) observed that adding 3 and $5 \%$ bentonite clays to the ration of 
chicken reduced significantly $(\mathrm{P} \leq 0.05)$ the water content of the droppings than the control. In addition, Taylor (1999) reported that supplementing acidulated clay to the litter significantly $(\mathrm{P} \leq 0.05)$ reduced the ammonia level than that of the untreated litter type group. McWard and Taylor (2000) suggested that using the clay as component of litter s could control the amount of ammonia and improve the growth performance of the growing birds. Ouachemand Kaboul (2012) found that the clay contribute significantly $(\mathrm{P}=0.02)$ to increase the dry matter of droppings by about $18 \%$.

The results of Mumpton, (1999) revealed that the animal feed containing clay as kaolin promoted the weight gain, improved the feed efficiency and reduced the bacterial contamination in the gut. Similarly, Taugir and Nawaz, (2001) stated that the clay reduced the detrimental effects of contaminated dusts with mycotoxin. The addition of lay (Kaolin) to the diet was also found to protect the intestinal mucosa of the beef, by adhering the pathogens and promoting their excretion. This may have been responsible for the obtained low feed intake and the improved feed conversion ratio in the treated groups (Droy-Lefain et al., 1985).

\section{Economical Efficiency}

The results presented in Table (4), showed that, birds raised on $\mathrm{L} 1$ had relatively higher economical efficiency than those of birds raised on $\mathrm{C}$ or L2, since it amounted 100.0, 107.1 and $100.6 \%$, respectively. This is in harmony with the results of El-Sagheer et al. (2009), who showed that Dandarawi birds raised on litter consisted of $25 \%$ of each of rice hulls, chopped wheat straw, wood sawdust and clay had higher economical efficiency than those of Dandarawi birds raised on $100 \%$ chopped wheat straw litter or $20 \%$ of each of rice hulls, wheat straw, wood sawdust and $40 \%$ clay litter, since it amounted 100, 124 and 84, respectively. In addition, Safaei Katouli et al. (2012) and Zarin Kavyani et al. (2007) reported that the supplementation 3\% zeolite clay to the diet of chicken's broiler improved significantly the European Efficiency Factor (EEF).

Table 4. Economical efficiency as affected by litter type

\begin{tabular}{|c|c|c|c|c|}
\hline \multirow{2}{*}{\multicolumn{2}{|c|}{ Items }} & \multicolumn{3}{|c|}{ Groups } \\
\hline & & $\mathbf{C}$ & L1 & L2 \\
\hline \multirow{3}{*}{ Total costs/ bird/L.E } & Litter costs/bird (LE) & 0.034 & 0.028 & 0.020 \\
\hline & Feed costs (LE/bird) & 1.84 & 1.84 & 1.84 \\
\hline & Total costs/ bird/LE & 1.87 & 1.87 & 1.86 \\
\hline \multicolumn{2}{|c|}{ Selling price of live bird at 8 weeks of age (L.E) } & 4.92 & 5.14 & 4.92 \\
\hline \multicolumn{2}{|c|}{ Net revenue/bird/L.E (without constant costs ${ }^{*}=25 \%$ ) } & 3.05 & 3.27 & 3.06 \\
\hline \multicolumn{2}{|c|}{ Economical efficiency/bird (EE) } & 1.66 & 1.77 & 1.67 \\
\hline \multicolumn{2}{|c|}{ Relative economical efficiency/bird (REE)/bird (EE) } & 100.0 & 107.1 & 100.6 \\
\hline
\end{tabular}

Cost of $1 \mathrm{~kg}$ of carcass weight $=24.00$ LEPrice of $1 \mathrm{~kg}$ of ration $=2.6 \mathrm{LE} \quad \mathrm{LE}=$ Egyptian pound.

*Constant costs include: housing, labour, heating, cooling, lighting and treatment regimens.

$\mathrm{C}=100 \%$ wheat straw.

$\mathrm{L} 1=25 \%$ rice hulls, $25 \%$ wheat straw , $25 \%$ wood sawdust and $25 \%$ clay mix.

L2 $=20 \%$ rice hulls, $20 \%$ wheat straw, $20 \%$ wood sawdust and $40 \%$ clay mix.

\section{CONCLUSION}

It could be concluded that the use of mixed litter composing of $25 \%$ of each of rice hulls, wheat straw, wood sawdust and clay is recommended as an economical litter for growing Japanese quail.

\section{REFERENCES}

Adebayo, I.A., T.A.M. Awoniyi and A.H. Akenroye, 2009. Growth performance and meat wholesomeness of broiler chickens reared on different types of litter materials. Journal of Food, Agriculture \& Environment, 7 (3\&4): 209 - 213. www.world-food.ne. http://world-food.net/download/journals/2009issue 3 4/1(2).pdf.
Alzueta, C., L.T. Ortiz, A. Rebole, M.L Rodriguez, C. Centreno and J. Trevino, 2002. Effects of remoral of mucilageand enzyme of sepiolite supplement on the nutrient digestibility and metabolizable energy of a diet containing linseed in broiler chickens. Animal Feed Science Technology, 97: 169181.

Andersson, I., B. Teglof and K. Elwinger, 1990. Transfer of $137 \mathrm{Cs}$ from grain to eggs and meat of laying hens and meat of broilers chickens and the effect of feeding bentonite. Swedish Journal of Agriculture Research, 20 (1): 35-42.

Andronikashvili, T.G., B.S. Tsereteli, V.K. Dolidze and N.G. Iremashvili, 1994. Zeolite supplements in diets for birds. Zootekhniya, S: 17-18.

Atapattu, N.S.B.M., D. Senaratna and U.D. Belpagodagamage, 2008. Comparison of 
ammonia emission rates from three types of broiler litters. Poultry Science, 87 (12): 2436-2440.doi: 10.3382/ps.2007-00320. PMID: 19038797.

Atencio, J.L., J.A. Fernàndez, A.G. Gernat and J.G. Murillo, 2010. Effect of pine wood shavings, rice hulls and river bed sand on broiler productivity when used as a litter sources. International Journal of Poultry Science, $\quad 9 \quad$ (3): $240-$ 243.DOI: 10.3923/ijps.2010.240.243. http://scialert.net/qredirect.php?doi=ijps.2010.240.243 \&linkid $=p d f$.

Christaki, E., P. Florou-Paneri, A. TserveniGousi, A. Yannakopoulos and P. Fortomaris, 2001. Effects of dietary inclusion of a natural zeolite on broiler performance and carcass characteristics. Proceedings of the $13^{\text {th }}$ International Zeolite Conference: "Zeolites and mesoporous materials at the dawn of the $21^{\text {st }}$ century", Montpellier, France, pp. 17.https://books.google.com.eg/books?isbn=008054391X

Droy-Lefain, M.T., T. Drouet and B. Schatz, 1985. Sodium glycodeoxycholate and spinability of gastrointestinal mucus: protective effect of smectitite. Gastroenter, 88 (Supplemental 2): 1369.

Duncan, D.B., 1955. Multiple range and multiple F tests. Biometrics, 11: 1-42.

Eleroğlu, H. and H. Yalçin, 2005. Use of natural zeolitesupplemented litter increased broiler production. South African Journal of Animal Science, 35, 90-97.

El-Sagheer, M., H.Y. El-Hammady and M.F.A. Farghly, 2009. Effect of litter type on productive performance of growing and laying Dandarawi chicken. The $5^{\text {th }}$ International Poultry Conference, 10-13 March, Taba-Egypt, R (18): 1591-1615. Google scholar.

Erwin, E.S., C.J. Elam and I.A. Dyer, 1957. The influence of sodium bentonite in vitro and in the ration of steers. Journal of Animal Science, $16 \quad$ (4): $\quad 858-862$. doi:10.2134/jas1957.164858x.

https://www.animalsciencepublications.org/publications/ jas/abstracts/16/4/JAN0160040858.

Grimes, J.L., T.A. Carter and J.L. Godwin, 2006. Use of a litter material made from cotton waste, gypsum, and old newsprint for rearing broiler chickens. Poultry Science 85 (3): 563-568. doi: 10.1093/ps/85.3.563 PMID: 16553290.

Gupta, G. and W. Gardner, 2005. Use of clay mineral (montmorillonite) for reducing poultry litter leachate toxicity (EC50). Journal of Hazardous Materials, Volume 118, Issues 1-3, 14 February, Pages 8183.doi:10.1016/j.jhazmat.2004.05.024PMID: 15721531.

Karamanlis, X., P. Fortomaris, G. Arsenos, I. Dosis, D. Papaioannou, C. Batzios and A. Kamarianos, 2008. The effect of a natural zeolite (clinoptilolite) on the performance of broiler chickens and the quality of their litter. Asian-Australian Journal of Animal Sciences, $21 \quad$ (11): $\quad 1642$

1650. doi: http://dx.doi.org/10.5713/ajas.2008.70652 http://www.ajas.info/upload/pdf/21229.pdfwww.ajas.info.

Kiaei, S. M. M., M. Modirsanei, M. Farkhoy, and A. Taghdiri, 2002. Effects of diatomite and natural zeolite supplementation on the performance of broiler chicks and litter moisture. Veterinary Department Journal, Tehran University, 57 (2): 19-24.

Klement, Z., K. Rudolph and D.C. Sands, 1990. Methods in phytobacteriology. Academiai Kiado, Budapest, December 1990, pp 568.http://www.amazon.com/MethodsPhytobacteriology-Z-Klement/dp/9630549557.

Lien, R.J., D.E. Conner and S.F. Bilgili, 1992. The use of recycled paper chips as litter material for rearing broiler chickens. Poultry Science, 71 (1): 81-87.doi: 10.3382/ps.0710081. http://ps.oxfordjournals.org/content/71/1/81.full.pdf + ht $\underline{m l}$.

McCollum, F.T. and M.L. Galyean, 1983. Effect of clinoptiololits on rumen fermentation, digestion and feed lot performance in beef stress fed high concentrate diet. Journal of Animal Science, $56 \quad$ (3): 517-524. PMID:6302059.

McCrory, D.F. and P.J. Hobbs, 2001. Additives to reduce ammonia and odor emissions from livestock wastes: a review. Journal of Environmental Quality, 30 (2):345-355.PMID: 11285894doi:10.2134/jeq2001.302345x.

McWard, G.W. and D.R. Taylor, 2000. Acidified clay litter amendment. The Journal of Applied Poultry Research, 9 (4): 518-529. doi: 10.1093/japr/9.4.518.

http://japr.oxfordjournals.org/content/9/4/518.full.pdf $+h$ tml.

Mumpton, F.A., 1999. La roca magica: uses of natural zeolites in agriculture and industry. Proceedings of the National Academy of Sciences of United States of America, 1999 $\begin{array}{llll}\text { Mar } & 30, & 96 & \text { (7): 3463-3470. doi: }\end{array}$ 10.1073/pnas.96.7.3463.PMID: 1009705.

NRC, National Research Council, 1994. Nutrient Requirements of Poultry. $9^{\text {th }}$ Review Edition, National Academy Press, Washington, D.C.http://www.lamolina.edu.pe/zootecnia/biblioteca20 12/NRC\%20Poultry\%201994[1].pdf.

Nodvor, D., 1976. Practice of hygiene with technical sanitary measures. Medicine, 7: 254-280.

Ouachem, D. and N. Kaboul, 2012. The Marl as a Natural Supply on Broiler Chicken Feed: Effects on the Starter Performance, the Abdominal Fat and the Dropping Moisture. International Journal of Poultry Science, 11 (3): 225-228. DOI: 10.3923/ijps.2012.225.228. http://scialert.net/abstract/?doi=ijps.2012.225.228.

Quisenberry, J.H. and J.W. Bradley, 1964. Sodium bentonite feeding experiments. Feedstuffs, 36: 22-23. 
Quisenberry, J.H., 1968. The use of clay in poultry feed. Clays and Clay Minerals, 16: 267-270.DOI: 10.1346/CCMN.1968.0160402 http://www.allnaturalpetcare.com/Animal_Nutrition_Res earch/Use_of_Clay_in_Poultry_Feed.pdf.

Safaei Katuli, M., F. Boldaji, B. Dastar and S.Hassani, 2012. The effect of dietary silicate minerals supplementation on apparent ileal digestibility of energy and protein in broiler chickens. International Journal of Agriculture \& Biollogy, $14 \quad$ (2): 299 302.www.scholar.google.com/citations? user $=0 y$ hgHVA AAAAJ\&hl=en.

http://scientificfinding.gau.ac.ir/uploading/scientificfindi ng.gau.ac.ir/images/dastar/2012_safaeikatoulie 299 30 2.pdf.

SAS Institute, 1996. SAS® Users Guide, Version 6.12. SAS Institute, Cary, NC.http://support.sas.com/rnd/itech/updates/91/dev gu ide.pdf.

Swain, B.K. and R.N.S. Sundaram, 2000. Effect of different types of litter material for rearing broilers. British Poultry Science, 41 (3): 261262. DOI: 10.1080/713654931. PMID: 11081418.

Tauqir, N.A. and H. Nawaz, 2001. Performance and economics of broiler chicks fed on rations supplemented with different levels of sodium bentonite. International Journal of Agriculture \& Biology, 3 (1): 149-150. http://www.fspublishers.org/published_papers/78704_..p df.
Taylor, D.R., 1999. Poultry Guard: A new poultry litter amendment. Paper S3 in: Proceeding 1999 Southern Poultry Science Society, $20^{\text {th }}$ Annual Meeting, Atlanta, GA.

Veltmann, J.R., F.A. Gardner and S.S. Linton, 1984. Comparison of rice hull products as litter material and dietary fat levels on turkey poultry performance. Poultry Science, 63 (12): $\quad$ 2345-2351.doi: 10.3382/ps.0632345. http://ps.oxfordjournals.org/content/63/12/2345.full.pdf + thtml.

Xia, M.S., C.H. Hu and Z.R. Xu, 2004. Effects of copper-bearing montmorillonite on growth performance, digestive enzyme activities and intestinal micro-flora and morphology of male broilers. Poultry Science, 83 (11): 1663 1875.doi: 10.3382/ps. 0722172 .

Zarin Kavyani, K., B. Shokrolaji and S.M. Mosavai, 2007. The effect of natural zeolite on production feed cost of Lohmann chicks. Veterinary Journal Islamic, Azad University, $1(2): 35-4$.

Zlobina, I.E., 1990. Retention of trace elements from zeolite in birds and the effect of pegasin on the meat quality of broiler chickens. Sibirskoe Otdelenie, Sibirskii Nauchno Issledovsl"ski I Proektno Teknologicheskii Institute Zhivotnovodstva, 2: 28-30. doi: 10.1093/ps/83.11.1868.

\footnotetext{
ظروف الهواء داخل المسكن و اداء النمو للسمان اليابانى المربى على أنواع فرشة مختلفة محمد فرغلي علم الاين فرغلي، محمد الصغير محمد حسن، حاتم يوسف الحمادى قسم إنتاج الدواجن، كلية الزراعة، جامعة أسبيوط، مصر

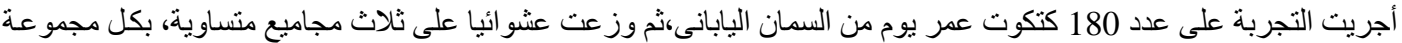

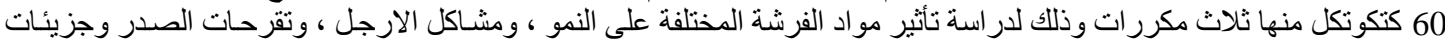

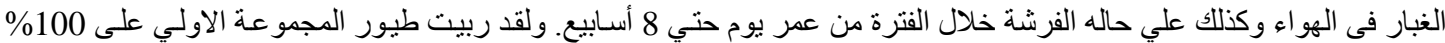

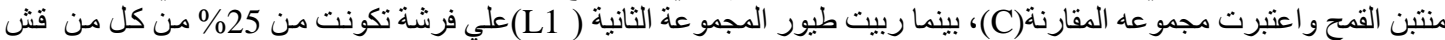

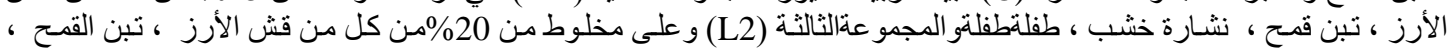

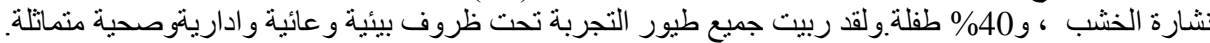

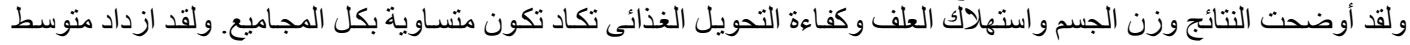

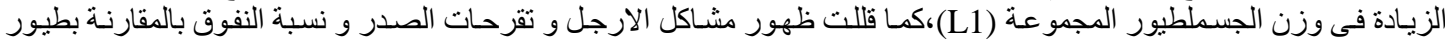

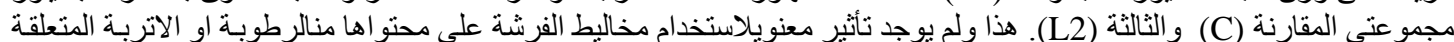

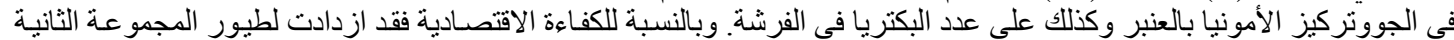

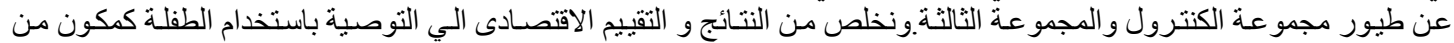

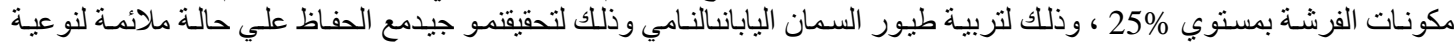
الفرشة وجو العنبر.
} 